\title{
Relative importance of formiminoglutamic and urocanic acid excretion after a histidine load
}

\author{
S. D. MOHAMED AND M. ROBERTS \\ From the Department of Materia Medica and Therapeutics, \\ University of Aberdeen, and the Royal Infirmary, Aberdeen
}

SYNOPSIS A thin-layer chromatographic method for the simultaneous assessment of formiminoglutamic (Figlu) and urocanic acid excretion after loading with $15 \mathrm{~g}$. histidine has been applied to 15 control subjects and to 49 selected patients. Upper limits of normal excretion were determined for urocanic acid and Figlu alone $(15 \mathrm{mg}$. and $30 \mathrm{mg} . / 8 \mathrm{hr}$. respectively), and for the combined metabolites $(40 \mathrm{mg} . / 8 \mathrm{hr}$.). Of the 49 patients studied, 27 excreted total metabolites above $40 \mathrm{mg} . / 8$ hr.; of these 19 would have been revealed by their abnormal excretion of Figlu and 22 by their abnormal excretion of urocanic acid. Of 74 tests in the 64 subjects, urocanic acid was present in all but $27 \%$ of the tests, and in $29.8 \%$ of the tests urocanic acid was in excess of the amount of Figlu excreted. In six normal and six abnormal tests urocanic acid was the sole metabolite present. These results re-emphasize the value of estimating both histidine metabolites in tests for folate deficiency in man, and underline the greater relative importance of urocanic acid.

The metabolic fate of L-histidine, summarized in Fig. 1, has been the subject of renewed interest because of the realization that some stages of its breakdown to glutamic acid are folate dependent (Bakerman, Silverman, and Daft, 1951; Borek and Waelsch, 1953; Tabor, Silverman, Mehler, Daft, and Bauer, 1953; Seegmiller, Silverman, Tabor, and Mehler, 1954). This interest has been further enhanced by the fact that the amount metabolized to glutamic acid can be augmented by suitable histidine loading (Tabor et al., 1953; Luhby, Cooperman, and Teller, 1959a and b; Spray and

Received for publication 7 September 1965

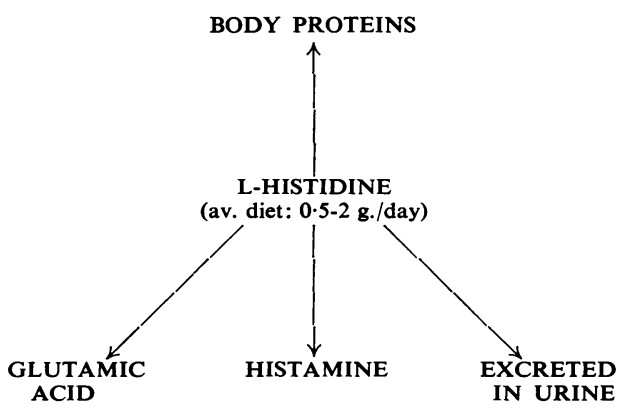

FIG. 1. Metabolic fate of L-histidine
Witts, 1959), and that the intermediates of this metabolic pathway are readily accessible for examination in the urine.

In the absence of a competent folic acid coenzyme to act as an acceptor for the formimino group, formiminoglutamic acid (Figlu, Fig. 2) accumulates and is excreted in the urine. Several workers have reported significant increases in the urinary excretion of this metabolite in nutritional folic acid deficiency and in a variety of diseased states where factors other than dietary deficiency of folic acid operate to produce what might be described as 'conditioned

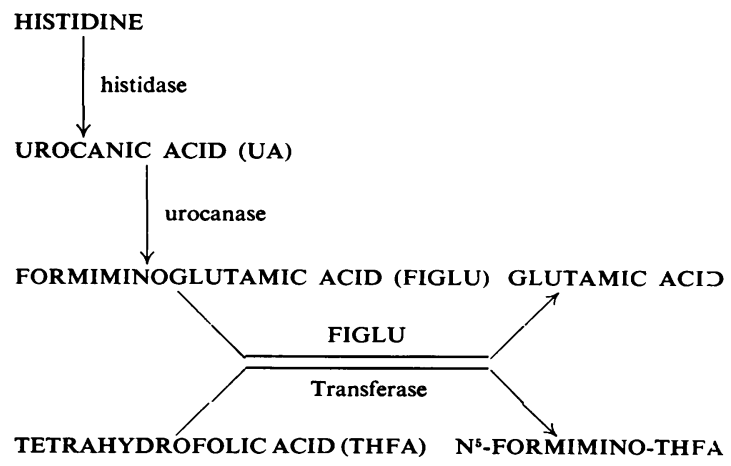

FIG. 2. Breakdown of histidine to glutamic acid 
folate deficiency' and these have been well reviewed recently by Luhby and Cooperman (1964). The suggested conditioning factors have included malabsorption, increased demand and increased utilization of folic acid, interference with the proper functioning of the folate coenzymes due to vitamin $B_{12}$ deficiency, antagonism from synthetic therapeutic substances and even hypothetical naturally occurring folic acid antagonists, defective hepatic storage, and deficiency of the enzyme Figlu transferase, an apoenzyme in the liver which acts with tetrahydrofolic acid in the transfer of the formimino group (Fig. 2). Estimation of urinary Figlu, with or without histidine loading, is widely regarded as a useful and sensitive biochemical index of folate deficiency.

However, Acheson, Paul, and Tomlinson (1958) identified a precursor of Figlu, urocanic acid, in small amounts in normal urine, and in the same year Baldridge (1958) demonstrated a decrease in liver urocanase activity in folate-deficient rats. More recently, Bennett and Chanarin (1962) have demonstrated the presence of urocanic acid on histidine loading in $88 \%$ of a large number of patients with a variety of clinical disorders, including megaloblastic anaemia. In 79 of the 186 samples, urocanic acid exceeded the amounts of Figlu excreted and 10 patients excreted only urocanic acid. Inhibition of urocanase by high tissue Figlu levels with subsequent build-up of urocanic acid was considered as a possible mechanism. Reactivation of urocanase by the rising tissue levels of urocanic acid would, in turn, result in the reappearance of Figlu in the urine. Chanarin (1963) has since described a patient with megaloblastic anaemia showing an alternating pattern of Figlu and urocanic acid excretion on serial testing, as would be expected on this hypothesis.

Despite this important work, histidine load tests continue to be assessed widely on the basis of Figlu excretion only. The main reason for this is the technical difficulty of estimating Figlu and urocanic acid simultaneously. The spectrophotometric modification of the enzymatic assay developed by Chanarin and Bennett (1962) is tedious and time consuming, and the crude liver enzyme preparation used contains a variety of enzymes, including histidase and urocanase, both of which are potentially liable to introduce artefactual alterations in the amounts of Figlu and urocanic acid (Luhby and Cooperman, 1964).

We have recently reported the use of ascending chromatography on thin layers of cellulose as a relatively simple, sensitive, and rapid method for simultaneous separation and semi-quantitative estimation of Figlu and urocanic acid (Mohamed and Roberts, 1964; Roberts and Mohamed, 1965). The method has now been used to estimate the urinagy excretion of these two metabolites on histidine load: ing in a representative group of cases and the resules have been examined to assess the claim of Bennest and Chanarin in respect of urocanic acid.

\section{PATIENTS, MATERIALS, AND METHODS}

PATIENTS The 64 subjects studied are listed in Table I⿰氵㔾

The 15 control subjects were eight healthy adutt members of the staff, and seven patients, who had no evidence of any gastrointestinal or haematologicall abnormality or conditions likely to produce folade deficiency.

All five patients with the malabsorption syndrome were anaemic with a 'dimorphic' peripheral blood picture, bạ only three showed megaloblastic erythropoiesis. Three patients had a histamine-fast achlorhydria. In two \& these, and in one patient with free acid, a jejunal biopgy was performed, and this showed partial or subtotal villous atrophy. All five patients showed flat glucose tolerance curves, subnormal excretion of D-xylose, and a flocculetion pattern on $x$-ray examination of the small intestin but only four had frank steatorrhoea. The fat excretion the remaining patient averaged $4.8 \mathrm{~g}$./day. Of the four patients in whom it was tested, vitamin $B_{12}$ absorptiơ was subnormal in two but was not in the range characte? istic of pernicious anaemia. In only one of these could G be corrected by the administration of hog intrinsic facto A complete haematological response to folic acid was obtained in four of the five patients after an initial sue optimal response to vitamin $\mathbf{B}_{\mathbf{1 2}}$. The remaining patierf showing a mild dimorphic anaemia with normoblaste erythropoiesis, responded to a gluten-free diet alone. $\overrightarrow{\vec{O}}$

All six patients with pernicious anaemia were previous untreated cases who had megaloblastic anaemia, hista mine-fast achlorhydria, and a defect of vitamin $\mathrm{B}_{\overline{\mathrm{Q}}}$ absorption which could be corrected by giving hog intrinsic factor. A classical response to vitamin $\mathrm{B}_{\mathrm{O}}^{\mathrm{P}}$ therapy occurred in each case.

The patient with Crohn's disease was a young woma of 24 with moderate hypochromic, normoblastic anaemi\&, a flat glucose tolerance curve, and malabsorption of D-xylose and fat. She had radiological evidence of regional ileitis involving the terminal ileum. An 18-inch portion of the diseased bowel was subsequently resecter

The 17 patients with partial gastrectomy all had had? Polya repair five or more years earlier and none was anaemic at the time of the test.

Cirrhosis of the liver in both patients was of the cryptogenic variety, and both had liver cell failure, with moderate normochromic anaemia, leucopenia, ang thrombocytopenia. The patient with cardiac failure was woman of 84 with valvular heart disease and moderafe iron-deficiency anaemia.

Of the nine patients with thryotoxicosis, two had assoct ated diseases; one, a boy of 15 , had an iron-deficiency anaemia with splenomegaly, and he responded well afte treatment with iron; and the other was a man of 54 wh had undergone a mitral valvotomy 18 months earlier and had subsequently remained free of congestive failure auricular fibrillation being controlled with digitalis. 
TABLE I

SEVENTY-FOUR HISTIDINE LOAD TESTS IN 64 SUBJECTS

\begin{tabular}{|c|c|c|c|c|c|}
\hline \multirow[t]{2}{*}{ Case No. } & \multirow[t]{2}{*}{ Condition } & \multirow[t]{2}{*}{ No. of Cases } & \multicolumn{3}{|c|}{ Histidine Metabolites (mg./8 hr. $)^{1}$} \\
\hline & & & Figlu & Urocanic Acid & Total \\
\hline 1 to 15 & 'Control' subjects & 15 (24 tests) & $0-30$ & $0-20$ & $0-35$ \\
\hline $\begin{array}{l}16 \\
17 \\
18 \\
19 \\
20\end{array}$ & Malabsorption syndrome & 5 & $\begin{array}{c}140 \\
350 \\
350 \\
140 \\
120\end{array}$ & $\begin{array}{r}50 \\
15 \\
90 \\
0 \\
50\end{array}$ & $\begin{array}{l}190 \\
365 \\
440 \\
140 \\
170\end{array}$ \\
\hline $\begin{array}{l}21 \text { to } 24 \\
25 \\
26\end{array}$ & Pernicious anaemia & $6\left\{\begin{array}{r}\text { Normal } 4 \\
\text { Abnormal } 2\end{array}\right.$ & $\begin{array}{r}0-15 \\
140 \\
140\end{array}$ & $\begin{array}{r}5-20 \\
70 \\
0\end{array}$ & $\begin{array}{r}5-25 \\
210 \\
140\end{array}$ \\
\hline $\begin{array}{l}27 \text { to } 40 \\
41 \\
42 \\
43\end{array}$ & Partial gastrectomy & $17\left\{\begin{array}{rr}\text { Normal } 14 \\
\text { Abnormal } 3\end{array}\right.$ & $\begin{array}{r}0-30 \\
70 \\
0 \\
0\end{array}$ & $\begin{array}{r}0-10 \\
20 \\
50 \\
70\end{array}$ & $\begin{array}{r}0-30 \\
90 \\
50 \\
70\end{array}$ \\
\hline $\begin{array}{l}44 \\
45 \\
46 \\
47\end{array}$ & $\begin{array}{l}\text { Crohn's disease } \\
\text { Cirrhosis of liver } \\
\text { Cirrhosis of liver } \\
\text { Congestive failure: valvular heart disease }\end{array}$ & $\begin{array}{l}1 \\
2 \\
1\end{array}$ & $\begin{array}{r}0 \\
70 \\
50 \\
0\end{array}$ & $\begin{array}{r}60 \\
100 \\
150 \\
90\end{array}$ & $\begin{array}{r}60 \\
170 \\
190 \\
90\end{array}$ \\
\hline $\begin{array}{l}48 \text { to } 50 \\
51 \\
52 \\
53 \\
54 \\
55 \\
56\end{array}$ & Thyrotoxicosis & $9\left\{\begin{array}{r}\text { Normal } 3 \\
\text { Abnormal } 6\end{array}\right.$ & $\begin{array}{r}0-15 \\
0 \\
80 \\
10 \\
50 \\
0 \\
90\end{array}$ & $\begin{array}{r}0-15 \\
45 \\
160 \\
80 \\
0 \\
80 \\
10\end{array}$ & $\begin{array}{r}0-30 \\
45 \\
240 \\
90 \\
50 \\
80 \\
100\end{array}$ \\
\hline $\begin{array}{l}57 \\
58 \\
59 \\
60 \\
61 \\
62 \\
63 \\
64\end{array}$ & $\begin{array}{l}\text { Carcinoma of bronchus } \\
\text { Carcinoma of bronchus } \\
\text { Carcinoma of bronchus } \\
\text { Carcinoma of stomach } \\
\text { Acute monocytic leukaemia } \\
\text { Malignant myelosclerosis } \\
\text { Myelofibrosis: pernicious anaemia } \\
\text { Erythraemic myelosis }\end{array}$ & $\begin{array}{l}1 \\
1 \\
1 \\
1 \\
1\end{array}$ & $\begin{array}{l}80 \\
30 \\
0 \\
35 \\
160(180)^{2} \\
50 \\
120 \\
25\end{array}$ & $\begin{array}{l}10 \\
140 \\
0 \\
5 \\
25(30)^{2} \\
80 \\
60 \\
950\end{array}$ & $\begin{array}{l}90 \\
170 \\
0 \\
40 \\
185(210)^{2} \\
130 \\
180 \\
975\end{array}$ \\
\hline
\end{tabular}

${ }^{1}$ Excretions of Figlu (formiminoglutamic acid) and urocanic acid in the different disease groups are expressed as the observed range when the results were normal; individual values are shown where the combined excretion of the two metabolites was in excess of normal.

${ }^{2}$ Results of repeat tests.

The last group of patients had malignant disease. There were three cases of bronchial carcinoma, and a case each of gastric carcinoma, acute monocytic leukaemia, malignant myelosclerosis, erythraemic myelosis, and myelofibrosis. The last patient, whom we have reported elsewhere (Roberts and Mohamed, 1965), also showed a megaloblastic anaemia with defect of vitamin $B_{12}$ absorption of the type found in pernicious anemia.

TEST URINES These were collected over an eight-hour period after a loading dose of $15 \mathrm{~g}$. of L-histidine monohydrochloride. Aliquots of the measured total volume were stored at $-20^{\circ} \mathrm{C}$. until the time of the assay.

ESTIMATION OF FIGLU AND UROCANIC ACID This was carried out by the semi-quantitative method on thin-layer chromatograms, as described previously (Mohamed and Roberts, 1964; Roberts and Mohamed, 1965).

\section{RESULTS}

The eight-hour excretions of Figlu and urocanic acid in 24 tests in the 15 control subjects are shown individually in Figure 3 . The mean combined excretion of the two metabolities was $13.8 \mathrm{mg}$. and the mean +2.32 standard deviation level, i.e., the level which would be expected to be exceeded by a normal subject once in 100 tests, was $38.6 \mathrm{mg}$., or approximately $40 \mathrm{mg}$.

Using the $40 \mathrm{mg}$. level for the combined excretion as the discriminant, it can be seen in Table $I$ that excretions in excess of this were found in all five patients with the malabsorption syndrome, in two of the six patients with pernicious anaemia, in the one patient with Crohn's disease, and in three of the 17 patients who had had a Polya gastrectomy. Both the patients with cirrhosis of the liver exceeded this figure, as did the one patient with cardiac failure, six of the nine thyrotoxic patients, and six of the eight patients with the various malignant diseases.

Table II shows the contribution of urocanic acid 


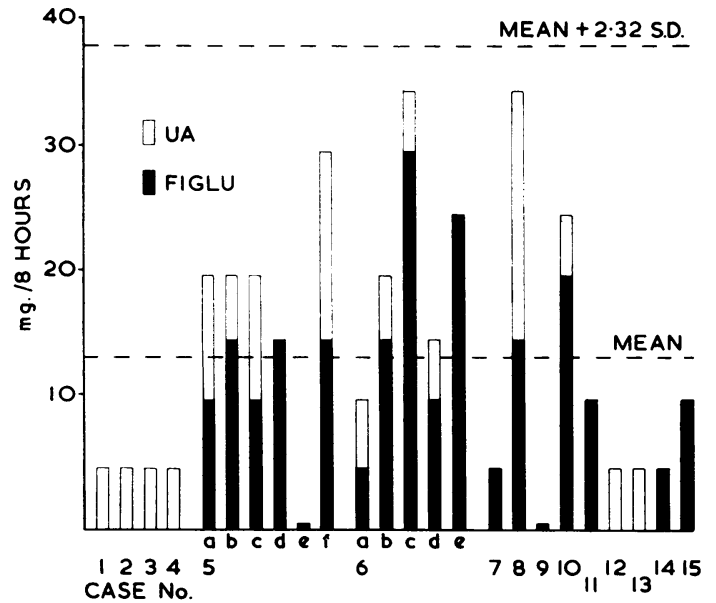

Fig. 3. Individual results of 24 histidine load tests in 15 control subjects. $U A=$ urocanic acid: Figlu $=$ formiminoglutamic acid. The mean and mean $\div 2.32$ standard deviation (S.D.) range of the combined excretion of Figlu and urocanic acid are shown.

to the total histidine metabolities observed in the individual diagnostic groups of cases. Of the 74 tests in 64 subjects, urocanic acid was present in all but $27 \%$ of the tests. In $29.8 \%$ of the tests urocanic acid was present in amounts in excess of Figlu. In fact, urocanic acid was the only metabolite present in 12 of the tests, and in six of these tests the amounts were considerably in excess of the normal excretion.

\section{TA BLE II}

CONTRIBUTION OF UROCANIC ACID TO HISTIDINE METABOLITES IN URINE

\begin{tabular}{|c|c|c|c|c|c|c|c|}
\hline \multirow[t]{2}{*}{ Diagnosis } & \multirow{2}{*}{\multicolumn{2}{|c|}{$\begin{array}{c}\text { No. } \\
\text { of } \\
\text { Tests }\end{array}$}} & \multicolumn{5}{|c|}{$\begin{array}{l}\text { Urocanic Acid as Percentage of } \\
\text { Total Histidine Metabolites }{ }^{1}\end{array}$} \\
\hline & & & 0 & $1-25$ & $26-50$ & $51-75$ & $76-100$ \\
\hline Normal controls & $(15)^{2}$ & 224 & 8 & 4 & 5 & 1 & 6 \\
\hline Steatorrhoea & (5) & 5 & 1 & 1 & 3 & 0 & 0 \\
\hline Pernicious anaemia & (6) & 6 & 1 & 0 & 3 & 0 & 2 \\
\hline Crohn's disease & (1) & 1 & 0 & 0 & 0 & 0 & 1 \\
\hline Partial gastrectomy & (17) & 17 & 6 & 6 & 2 & 0 & 3 \\
\hline Cirrhosis of liver & (2) & 2 & 0 & 0 & 0 & 2 & 0 \\
\hline Cardiac failure & (1) & 1 & 0 & 0 & 0 & 0 & 1 \\
\hline Thyrotoxicosis & (9) & 9 & 3 & 2 & 1 & 1 & 2 \\
\hline Malignancies (various) & $(8)$ & 9 & 1 & 5 & 0 & 1 & 2 \\
\hline Total & (64) & 74 & 20 & 18 & $\begin{array}{l}14 \\
\%)\end{array}$ & $\begin{array}{l}5 \\
(29 \cdot 8 \%\end{array}$ & 17 \\
\hline
\end{tabular}

${ }^{1}$ Numbers shown refer to actual numbers of tests in each group for the different ranges of excretion of urocanic acid expressed as a percentage of total histidine metabolites.

${ }^{2}$ Figures in brackets refer to number of cases in each group.

The statistical ranges of excretion of Figlu and urocanic acid in the 24 tests in the control subjects are shown in Table III. The upper limits of excretion
TABLE III

STATISTICAL RANGES OF EXCRETION OF FIGLU, UROCANI ACID, AND THE COMBINED EXCRETION OF THE TWO METABOLITES IN CONTROLS

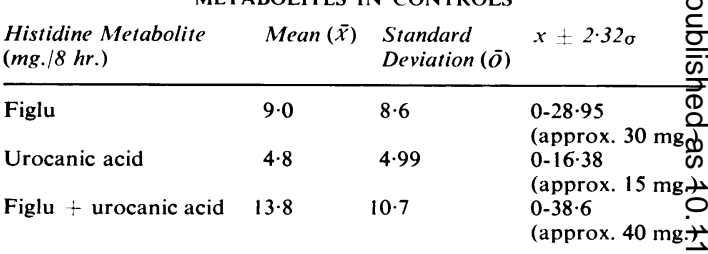

TABLE IV

DISCRIMINANT VALUE OF FIGLU, UROCANIC ACID, AND THIE COMBINED EXCRETION OF THE TWO METABOLITES

Diagnosis

\begin{tabular}{|c|c|c|c|}
\hline \multirow[t]{2}{*}{$\begin{array}{l}\text { No. } \\
\text { of } \\
\text { Tests }\end{array}$} & \multicolumn{3}{|c|}{$\begin{array}{l}\text { No. of Abnormal Tests for } \\
\text { Histidine Metabolites in Urine } \\
\text { as per }\end{array}$} \\
\hline & $\begin{array}{l}\text { Figlu } \\
(>30 \mathrm{mg} .)\end{array}$ & $\begin{array}{l}\text { Urocanic } \\
\text { Acid } \\
(>15 \mathrm{mg} .)\end{array}$ & $\begin{array}{l}\text { Figlu }+ \\
\text { Urocanic } \\
\text { Acid } \\
(>40 \mathrm{mg}\end{array}$ \\
\hline
\end{tabular}

\begin{tabular}{|c|c|c|c|c|c|}
\hline Normal controls & $(15)^{1}$ & 24 & - & 1 & - \\
\hline Steatorrhoea & (5) & 5 & 5 & 3 & 5 \\
\hline Pernicious anaemia & (6) & 6 & 2 & 2 & 2 \\
\hline Crohn's disease & (1) & 1 & 0 & 1 & 1 \\
\hline Partial gastrectomy & (17) & 17 & 1 & 3 & 3 \\
\hline Cirrhosis of liver & (2) & 2 & 2 & 2 & 2 \\
\hline Cardiac failure & (1) & 1 & 0 & 1 & 1 \\
\hline Thyrotoxicosis & (9) & 9 & 3 & 4 & 6 \\
\hline Malignancies various) & $(8)$ & 9 & 6 & 6 & 7 \\
\hline Total & (64) & 74 & $\begin{array}{l}19 \\
(70 \cdot 3 \%)\end{array}$ & $\begin{array}{l}23 \\
(85 \cdot 2 \%)\end{array}$ & $\begin{array}{l}27 \\
(100 \%)\end{array}$ \\
\hline
\end{tabular}

${ }^{1}$ Figures in brackets refer to the number of cases studied in each grou Upper limits of excretion of Figlu, urocanic acid, and Figlu 9 urocanic acid in the normal are statistically derived as shown Table III.

(mean +2.32 standard deviation) were approxi mately $30 \mathrm{mg}$. for Figlu, $15 \mathrm{mg}$. for urocanic acie़्, and $40 \mathrm{mg}$. for the combined excretion of the two metabolites. As can be seen in Table IV, of the 2.7 tests with adnormal combined excretion of Figlu ang urocanic acid, only $19(70.3 \%)$ can be identified b\% the estimation of Figlu alone. Simultaneous measure ment of urocanic acid, allowed an additional eigite cases to be identified as showing an abnormality of histidine metabolism.

\section{DISCUSSION}

Subclinical deficiency of folate has been shown to be very common in a variety of clinical conditions, and Luhby and Cooperman (1964) estimate that folate deficiency may be 'among the most prevalent, if not the most common, of the vitamin deficiencies of present-day man'. Serum folate levels were nof estimated in our patients, but the results of the histidine load tests in the malabsorption syndrom and pernicious anaemia are in conformity wite 
general experience with the Figlu test (Chanarin, 1960; Carter, Heller, Schaffner, and Korn, 1961; Herbert and Zalusky, 1962; Knowles and Prankerd, 1962; Chanarin, Bennett, and Berry, 1962; Luhby and Cooperman, 1964; Kershaw and Girdwood, 1964). The abnormal results in three of the 17 patients who had a Polya gastrectomy are comparable with the $10.4 \%$ incidence of folate deficiency, as assessed by bio-assay of serum folate activity (Deller, Ibbotson, and Crompton, 1964). These cases will be described in detail elsewhere.

Interference with folate metabolism, or a relative deficiency because of increased utilization, as assessed by increased urinary excretion of Figlu, subnormal urinary excretion of an oral dose of folic acid, rapid plasma clearance of an intravenous dose of folic acid, decreased liver content of folate, or even the presence of megaloblastic anaemia, have been described in malignant disease (Ehrlich and Lazarus, 1900; Swendseid, Swanson, Meyers, and Bethell, 1952; Girdwood, 1953; 1959; Broquist, 1956; Chanarin, Mollin, and Anderson, 1958; Chanarin et al., 1962; Romine, 1960; Chanarin, 1963; Villamil and McCracken, 1963; Karlin, 1963; Carey, Brena, and Krant, 1964; Kershaw and Girdwood, 1964; Dymock, 1964). Increased levels of Figlu and/or urocanic acid have been noted in cirrhosis of the liver (Luhby et al., 1959a; Carter, Schaffner, and Heller, 1960; Carter et al., 1961; Merritt, Rucknagel Silverman, and Gardiner, 1962; Knowles, Shaldon, and Fleming, 1963; Villamil and McCracken, 1963; Kershaw and Girdwood, 1964) and recently excessive amounts of Figlu have also been reported in patients in cardiac failure (Daly and Rose, 1964).

The abnormal results in six of the nine thyrotoxic patients, without significant complicating diseases, are of interest and these cases have been reported (Mohamed and Roberts, 1965). Theoretically, there are several ways in which thyrotoxicosis may interfere with folate metabolism: an increased requirement for folate consequent upon the general enhancement of metabolism or the known increase in red cell mass (Muldowney, Crooks, and Wayne, 1957) could account for it. The possibility of liver cell dysfunction in thyrotoxicosis (Cameron and Karunaratne, 1935; Maddock, Coller, and Pedersen, 1936; Shaffer, 1940; McIver and Winter, 1943; Piper and Poulsen, 1947; Myers, Brannon, and Holland, 1950; Movitt, Gerstl, and Davis, 1953) also merits consideration. It is of interest to note that low liver folate levels have been noted in rats rendered 'thyrotoxic' by feeding with iodinated casein (Noronha and Sreenivasan, 1959). Deficiency of Figlu transferase (Luhby and Cooperman, 1964) has been postulated in cirrhosis of the liver and in rheumatoid arthritis and this may also apply to thyrotoxicosis in man. Further studies to evaluate the possible role of some of these factors in thyrotoxicosis are in progress.

We think it reasonable to assume that the excessive combined excretion of Figlu and urocanic acid noted in 27 of the 64 patients in this series reflects either an absolute or relative deficiency of folate, or at any rate some abnormality of folate metabolism. Of these, only 19 patients were identified by measurement of urinary Figlu alone. Furthermore, urocanic acid was present in $73 \%$ of the 74 tests and in $29.8 \%$ of the tests the amounts were in considerable excess of Figlu. Six of the control subjects excreted only urocanic acid, as did six of the 27 patients with abnormal results.

These results are in strong agreement with those reported by Bennett and Chanarin and reinforce their suggestion that both Figlu and urocanic acid should be estimated in histidine load tests as an index of folate deficiency.

We wish to thank Professor A. G. Macgregor, Drs. J. Crooks, K. N. V. Palmer, C. D. Needham, J. M. Stowers, and Mr. C. G. Clark for access to cases under their care. Dr. M. J. Williams performed the jejunal biopsies and Dr. G. B. Scott assessed them histologically.

\section{REFERENCES}

Acheson, R. M., Paul, R. M., and Tomlinson, R. V. (1958). Canad. J. Biochem., 36, 295.

Bakerman, H. A., Silverman, M., and Daft, F. S. (1951). J. biol. Chem., 188, 117.

Baldridge, R. C. (1958). Ibid., 231, 207.

Bennett, M. C., and Chanarin, I. (1962). Nature (Lond.), 196, 271.

Borek, B. A., and Waelsch, H. (1953), J. biol. Chem., 205, 459.

Broquist, H. P. (1956). J. Amer. chem. Soc., 78, 6205.

Cameron, G. R., and Karunaratne, W. A. E. (1935). J. Path. Bact., 41, 267.

Carey, R. W., Brena, G. P., and Krant, M. J. (1964). Cancer, 17, 713.

Carter, F. C., Schaffner, G., and Heller, P. (1960). Clin. Res., 8, 199. Heller, P., Schaffner, G., and Korn, R. J. (1961). Arch. intern. Med., 108, 41.

Chanarin, I. (1960). Proc. 7th Congr. europ. Soc. Haemat., London, 1959, Part II/I, p. 52. Karger, Basle.

(1963). Brit. J. Haemat., 9, 141.

_, and Bennett, M. C. (1962). Brit. med. J., 1, 27. , and Berry, V. (1962). J. clin. Path., 15, 269.

Mollin, D. L., and Anderson, B. B. (1958). Proc. roy. Soc. Med., 51, 757.

Daly, J. J., and Rose, D. P. (1964). Communication (No. 12) to Medical Research Society, London, June, 1964.

Deller, D. J., Ibbotson, R. N., and Crompton, B. (1964). Gut., 5, 225.

Dymock, I. W. (1964). Lancet, 2, 114.

Ehrlich, P., and Lazarus, A. (1900). Histology of the Blood; Normal and Pathological, translated and edited by W. Myers. p. 116. Cambridge Univ. Press, London.

Girdwood, R. H. (1953). Brit. med. J., 2, 741.

(1959). Brit. med. Bull., 15, 14.

Herbert, V., and Zalusky, R. (1962). J. clin. Invest., 41, 1263.

Karlin, R. (1963). Path. et Biol., 11, 289.

Kershaw, P. W., and Girdwood, R. H. (1964). Scot. med. J., 9, 201.

Knowles, J. P., and Prankerd, T. A. J. (1962). Clin. Sci., 22, 233.

, Shaldon, S., and Fleming, A. (1963). Ibid., 24, 39.

Luhby, A. L., Cooperman, J. M., and Teller, D. N. (1959a). Amer. J. clin. Nutr., 7, 397. 
Luhby, A. L., Cooperman, J. M., and Teller, D. N. (1959b). Proc. Soc. exp. Biol. (N.Y.), 101, 350. -,-(1964). Folic Acid Deficiency in Man and Its Interrelationship with Vitamin $B^{12}$ Metabolism. In Advances in Metabolic Disorders, edited by R. Levine, and R. Luft, volume 1, pp. 263-334. Academic Press, New York and London.

McIver, M. A., and Winter, E. A. (1943). Arch. Surg., 46, 171.

Maddock, W. G., Coller, F. A., and Pedersen, S. (1936). West. J. Surg., 44, 513.

Merritt, A. D., Rucknagel, D. L., Silverman, M., and Gardiner, R. C. (1962). J. clin. Invest., 41, 1472.

Mohamed, S. D., and Roberts, M. Proc. 10th Congr. internat. Soc. Haemat., Stockholm, 1964. Abstracts, C ; 28.

- (1965). Lancet, 2, 933.

Movitt, E. R., Gerstl, B., and Davis, A. E. (1953). Arch. intern. Med., 91, 729.

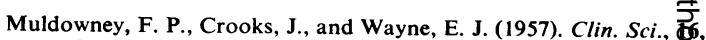
309.

Myers, J. D., Brannon, E. S., and Holland, B. C. (1950). J. clin. Inves: 29, 1069.

Noronha, J. M., and Sreenivasan, A. (1959). Biochem. J., 73, 732

Piper, J., and Poulsen, E. (1947). Acta med. scand., 127, 439.

Roberts, M., and Mohamed, S. D. (1965). J. clin. Path., 18, 214

Romine, M. K. (1960). J. Vitaminol., 6, 196.

Seegmiller, J. E., Silverman, M., Tabor, H., and Mehler, A. (1954). J. Amer. chem. Soc., 76, 6205.

Shaffer, J. M. (1940). Arch. Path., 29, 20.

Spray, G. H., and Witts, L. J. (1959). Lancet, 2, 702.

Swendseid, M. E. Swanson, A. L., Meyers, M. C., and Bethell,

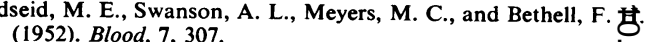

Tabor, H., Silverman, M., Mehler, A. H., Daft, F. S., and Bauer, $\mathbf{H}$. (1953). J. Amer. chem. Soc., 75, 756.

Villamil, A., and McCracken, B. H. (1963). Brit. med. J., 1, 717. 